\title{
CONTENT ON LINE
}

Moderator: Eduardo De Oliveira Silva

Engineer, PCP Advisor, Director of Engineering. EBCom

\section{Content generation on Multiple Platforms}

Speaker: Robson Ferri

Director - RF Mídia / Rádio Conteúdo

We are all almost 007s: Open Source Intelligence,

Smartphones, Social Networks and Investigative Journalism for the good of Citizenship

Speaker: Paulo Medeiro

CEO and Co-Founder / Orbis

\section{Conteúdo ONLINE - Riscos e Oportunidades para TV}

Speaker: Nelson Faria Jr

Vice-diretor Internacional da SET. Consultor de Tecnologia e Inovação da Consultoria Inovtec. Diretor-presidente da empresa Petchannel Comunicação.

\section{News Has No Owner}

Speaker: Raimundo Lima

Operation and Technical Director - SBT 


\section{4h00 - 16h00 | 29/08/2016 Monday | Room 14}

\section{Internet \& TV}

\section{Content ON LINE}

Moderator: EDUARDO DE OLIVEIRA SILVA - Engineer, PCP Advisor, Director of Engineering. EBCom

- Content generation on Multiple Platforms

Speaker: Robson Ferri

Director - RF Mídia / Rádio Conteúdo

A Palestra aborda como a produção de conteúdo online acompanha o ritmo das mudanças atuais.

- We are all almost 007s: Open Source Intelligence, Smartphones, Social Networks and Investigative Journalism for the good of Citizenship Speaker: Paulo Medeiro

CEO and Co-Founder / Orbis

Nowadays, intelligence activity is considered one of the critical elements in the strategy of a diverse range of organizations, whether public or private. The advances in information technologies require significant changes within traditional communication companies.

In this respect, smartphones and social networks anchored to the Internet play a key role among the existing means of communication. How to use Social Networks to counter violence? And in promoting public health? In fighting corruption? In producing exclusive and first-hand content? And how can, and should, Investigative Journalism use intelligence tools when going about its work?

\section{- Conteúdo ONLINE - Riscos e Oportunidades para TV} Speaker: Nelson Faria Jr Vice-diretor Internacional da SET. Consultor de Tecnologia e Inovação da Consultoria Inovtec. Diretor-presidente da empresa Petchannel Comunicação.

The rise of the Internet and other technological innovations have dramatically revolutionized the way in which we live our lives and how we consume media. The television industry, a model of stability since the 1950s, is now under intense pressure to sustain its revenues and margins in the face of competition on the Internet. With advertising revenues, in particular, under threat, can the networks continue to be sustainable without changing the nature of their programs?

\section{- News Has No Owner}

\section{Speaker: Raimundo Lima}

Operation and Technical Director - SBT

In the past very close, communication companies, writing newspapers, magazines, televisions or even news sites, had a monopoly of being the "official informants" of the population. Today, any CITIZEN ownership of a "smartphone", tablet, computer, camera, drone, etc., it is a potential producer of news. I challenge anyone to watch an edition of the news programs of any television station that does not contain at least one scene captured by an amateur, or a viewer scene recorded by security cameras. The ease of access to the media of capture and distribution of content, have become commonplace and the democratization of the role of information distributor. This multiple sources of supply, greatly impacted the routines and professionals of news production. 

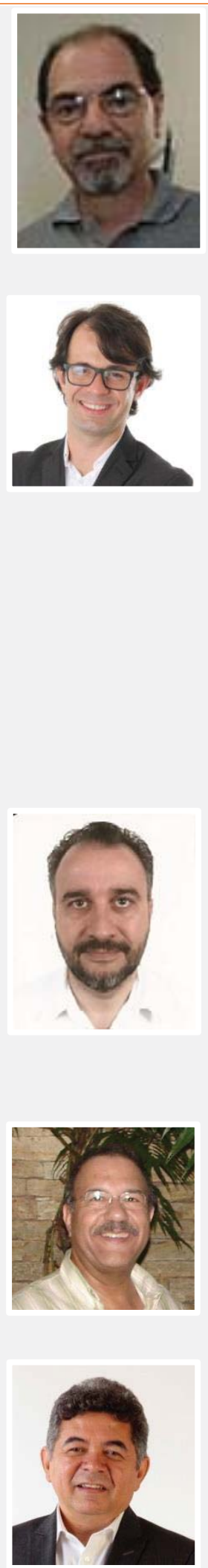

EDUARDO DE OLIVEIRA SILVA BICUDO - Co-owner - SET/ . EBCom

Engineer, with a graduate degree in telecommunications. Mackenzie Institute - 1976 to 1997 . Senior high school teacher and teacher at the school of engineering. Broadcasting Center Coordinator. Advisor to the president's office. TV Globo SP -1982 to 1998. Engineer, PCP Advisor, Director of Engineering. EBCom: 1998 - Today - Co-owner. Design and implementation of the Digital TV laboratory at the Mackenzie University; Coordinator of digital TV field measurements for the ISDB-T (Japanese) ATSC (USA) and DVB (European) systems. Manufacture of UHF antennae for Digital TV reception. Design and implementation of the TV Center of the Stock, Commodities and Futures Exchange. Others

\section{Robson Ferri - Director - RF Mídia / Rádio Conteúdo}

Robson Ferri has been in the radio profession for over 17 years, having worked for several radio stations in São Paulo market. These include: Rede Transamérica, Metropolitana Mix Fm. Owner of a content agency, www.radioconteudo.com.br, currently servicing over 170 broadcasters throughout Brazil, expanding into the delivery of content in Spanish to broadcasters in Latin America. We have customers in the USA and Portugal, where we make daily deliveries in a "ondemand" format to regional broadcasters in the artistic and commercial fields. These include programs, commercial inserts and marketing materials for our partners. In 2012, we generated content for over 100 broadcasters in Brazil and overseas, covering London during the Olympic Games, with an around-the-clock team of 24 professionals in England plugged into what was happening and constantly generating differentiated content. This year, 2016, we have the Torcida Brasil (Brazil Supporters Club) project, www.programatorcidabrasil.com.br, where we will deliver audio and video content to a much wider audience, with commercial support. I have given a series of talks in which I reiterate the importance of well-thought out content linked to a support, so that every department of a broadcaster achieves better results. The company is $100 \%$ aligned with the trend towards media convergence, where audio and video will once again go hand in hand.

PAULO MEDEIRO - CEO and Co-Founder - Orbis

A Computer Engineer, with a Master's in Artificial Intelligence from UCB/DF and an MBA in Foreign Trade and International Business, he worked for 14 years (1989-2003) as a Structural Projects Manager for the Brazilian Government, and for 10 years (2003-2013) he was Head of the Foreign Trade Intelligence Department at the International Trade Agency of the World Trade Organization in Geneva, Switzerland. A specialist in conceiving and managing intelligent systems for monitoring (on-line and broadcasting) media, extraction of information, cryptography and open source intelligence (OSINT) and is currently an entrepreneur in the field of technological innovation which, with the help of the Government of the United Kingdom, created Orbis (2016), a company specializing in global monitoring and the production of exclusive content.

NELSON FARIA JR - Vice-diretor Internacional da SET. Consultor de Tecnologia e Inovação da Consultoria Inovtec. Diretor-presidente da empresa Petchannel Comunicação.

An electronics engineer with an MBA in Finance and Marketing, he worked for 37 years at TV Globo in the Engineering Operations Department. He was also Advisor on Innovation and Technology at TV Globo. He is currently Deputy International Director of the Brazilian Society of Television Engineering, and Technology and Innovation Consultant at Consultoria Inovtec and Chief Executive Officer of Petchannel Comunicação SA

RAIMUNDO LIMA - Operation and Technical Director - SBT

Com mais de 34 anos de atividades na televisão aberta, ocupou diversos cargos e teve passagens pelas principais emissoras de televisão do país: SBT - Editor Executivo de Jornalismo e Diretor Técnico e de Operações. Esporte Interativo - Diretor de Produção; TV CULTURA/SP - Diretor de Operações; TV BAND - Chefe de Produção de Jornalismo, Diretor de Produção, Diretor de Operações e Tecnologia; TV GLOBO / GINY - Editor e Produtor; Diários Associados/TV Manchete - Diretor e Programas. FORMAÇÃO: UFF - Universidade Federal Fluminense - TV Digital e Novas Mídias Eletrônicas; PUC/SP - Jornalismo Multimídia; Sony Institute of Video Technology - Diversos; UNB - Universidade de Brasília 
GLOBO / GINY - Editor e Produtor; Diários Associados/TV Manchete - Diretor e Programas. FORMAÇÃO: UFF - Universidade Federal Fluminense - TV Digital e Novas Mídias Eletrônicas; PUC/SP - Jornalismo Multimídia; Sony Institute of Video Technology - Diversos; UNB Universidade de Brasília - Educação.

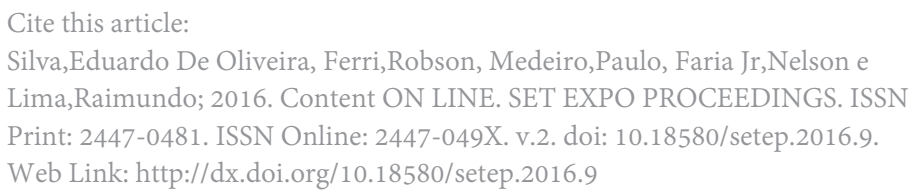

